\title{
Modernlik-Postmodernlik Ekseninde Serseri Âşıklar ve Mavi Kadife Filmlerinin Göstergebilimsel Karşılaştırılması
}

\author{
Nedret Çağlar (Dr. Öğr. Üyesi) \\ Süleyman Demirel Üniversitesi İletişim Fakültesi \\ nedretcaglar@sdu.edu.tr \\ Orcid: 0000-0001-9769-056X
}

Aslıhan Dumlu (Doktora Öğrencisi)

Süleyman Demirel Üniversitesi Sosyal Bilimler Enstitüsü

m.aslihandumlu@gmail.com

Orcid: 0000-0003-0017-5815

Başvuru Tarihi: 31.01.2019

Yayına Kabul Tarihi: 09.04.2019

Yayınlanma Tarihi: 22.07.2019

DOI: 10.17680/erciyesiletisim.520352

Çağlar, N. ve Dumlu, A. (2019). Modernlik-Postmodernlik Ekseninde Serseri Âşıklar ve Mavi Kadife Filmlerinin Göstergebilimsel Karşılaştırılması. Erciyes İletişim Dergisi, 6 (2), 1045-1064. DOI:

10.17680/erciyesiletisim.520352

Öz

Zihinde, dilde ve yaşamda yerleşik hâle gelmiş modernliğin yanı sıra bazıları için karşıtlık, bazıları için de süreklilik bağlamında modernlikle iliş̧ilendirilen postmodernlik, bu çalışmanın eksenini oluşturmaktadır. Kültürel, sosyal, ekonomik ve siyasal alanlarda farklı bakış açısı ile dikkat çeken postmodernizm, tek bir yapı içerisinde açıklanamamaktadır. Bu nedenle postmodernizmi anlayabilmek için aydınlanma çağının ve aynı zamanda modernliğin açıklanması gerekmektedir. Modernizmin ortaya çıkmasında etkili olan Rönesans, Reform ve Aydınlanma Çağı birbiriyle paralel gelișen ve birbirini tamamlayan olgular olarak değerlendirilmektedir.

Siyasal, toplumsal ve kültürel dönüşümlerin ortaya çıkarttığı modernizm, bireylere bir takım imkânlar vaad etmektedir. Modernizm, tek tipliği ve standartlara dayanan kalıpları benimsemiştir. $\mathrm{Bu}$ kalıplar da modernizme ve modernliğe karşı görüşlerin gelişmesine neden olmuştur. Modernizm ekseninde açıklanmaya çalışılan postmodernizmin ise kesin bir tanımı bulunmamaktadır. Bir anlatının anlamını değiştirerek yeni bir bakış açısıyla hem eskiyi sorgulayan hem de alternatifler üreten postmodernizm, modernizmden farklı ilkeleri benimsemiştir. Postmodernizm teklik karşısında çoğulculuğu, farklılı̆̆ı, yerelliği ve aynı zamanda bireyin modern olandan bağımsızlaşarak özgürleşmesini savunmaktadır.

Çalışmada modernlik-postmodernlik ilişkisi ve/veya karşıtlığı göstergebilimsel analiz üzerinden Jean-Luc Godard'ın "Serseri Âşılklar" ve David Lynch'in "Mavi Kadife" filmleri örnekleminde ele alınmıştır. Böylelikle modernlik-postmodernlik bağlamında anlam kazanmış görüşlerin, söz konusu filmler üzerinden değerlendirilmesi yapılmıştır.

Sonuç olarak örnek filmler incelendiğinde; modernizmi postmodernizmden kesin sınırlar ile ayırmak çok mümkün görünmemektedir. Bu iki terim hem birbirinden beslenen hem de birbirinden uç noktalarda ayrışan aynı bütünü farklı şekillerde yorumlama perspektifi olarak değerlendirilebilir.

Anahtar Kelimeler: Modernizm, Postmodernizm, Göstergebilimsel Analiz. 


\title{
Semiotic Comparison of "À Bout De Souffle" with "Blue Velvet" Films on the Axis of Modernity-Postmodernity
}

\author{
Nedret Çağlar (Asst. Prof. Dr.) \\ Süleyman Demirel University Faculty of Communication \\ nedretcaglar@sdu.edu.tr \\ Orcid: 0000-0001-9769-056X \\ Aslıhan Dumlu (Ph.D. Student) \\ Süleyman Demirel University Institute of Social Sciences \\ m.aslihandumlu@gmail.com \\ Orcid: 0000-0003-0017-5815
}

Date Received: 31.01.2019

Date Accepted: 09.04.2019

Date Published: 22.07.2019

DOI: 10.17680/erciyesiletisim.520352

\begin{abstract}
Along with the modernity embedded in mind, language and life, postmodernity, which is associated with contrast for some and with modernity in the context of continuity for the others, constitutes the axis of this study. Postmodernism which draws attention with its different point of views in cultural, social, economic and political fields, may not be explained in a single structure. It is therefore necessary to explain both the era of enlightenment and modernity so as to understand postmodernism. The Renaissance, Reform and Enlightenment Age, which are effective in the emergence of modernism, are considered as paralel developing and complementary facts.

Modernism created by political, social and cultural transformations promises individuals of a variety of possibilities. Modernism has adopted patterns based on uniformity and standards. These patterns have thus led to the development of views which are against modernism and modernity. There is no definitive definition of postmodernism which is tried to be explained on the axis of modernism. By changing the meaning of a narrative, postmodernism, which both questions the old and produces alternatives with a new perspective, has adopted different principles from modernism. Postmodernism advocates pluralism, difference, locality, as well as liberation of the individual through becoming independent from the modern one.

In the study, the relationship between modernity and postmodernity or the contrast between them were discussed in the sample of Jean-LucGodard's "A bout de Souffle" and David Lynch's "Blue Velvet" films through the semiotic analysis. In this way, the views that have gained meaning in the context of modernity-postmodernism, have been evaluated through the films in question.

Consequently; it does not seem very possible to distinguish modernism from postmodernism with certain boundaries. These two terms can be evaluated as the perspective of interpreting the same whole in different ways, which are both fed from each other and are separated from one another at the extreme points.
\end{abstract}

Keywords: Modernism, Postmodernism, Semiotic Analysis. 


\section{Giriş}

Modernite ve postmodernite literatürde hem birbirinin devamı sayılmakta hem de birbirinden farklı konumlandırılmaktadır. Bu yüzden modernite ve postmodernite hakkındaki tartışmalar hâlen daha devam etmektedir. Modernizm, Aydınlanma Çağı ile başlayan akımların ve yeni oluşumların önderliğinde ortaya çıkmıştır. Rönesans ve Reformdan sonra bireylerin, akılcılığı ön plana çıkartmaya başlamasının sonucunda kişisel hak, özgürlük ve eşitlik gibi kavramlar eşliğinde farkındalığının artması, modernizmin doğuşunu tetikleyen unsurlardan birisi olmuştur. Daha iyi bir dünya görüşü ile yola çıkan modernizm özellikle postmodernistler tarafından sıklıkla eleștiriye maruz kalmıştır.

"Post" eki ile geç dönem modernite ya da modernite sonrası anlamına gelen postmodernite; literatürde modernitenin reddi, modernitenin devamı ya da modernitenin karşıtı olarak tanımlanmaya çalışılmıştır. Postmodernizm temelinde standart olandan kopuşu savunmaktadır. Bu yüzden postmodernizm, modernizmin tektipçiliğini ve evrenselciliğini eleştirmektedir. Postmodernizm, modernizmin tahrip yaratacak merkezi olgularını aşmayı hedeflerken kendisinin de bunu ne kadar başarabildiği konusunda eleștirilmektedir. Bu konuda Murphy, postmodernizm ile aslında toplum genelindeki muğlak konuların dil ile gündeme getirilerek kültürün pasifleştirildiğini, toplumu bir arada tutan yasaların içeriğinin boşaltılarak işlevsiz hâle getirildiğini ve sonunda toplumsal kaosun desteklenmeye çalışıldığına vurgu yapmaktadır $(2000,85-86)$. Bunun bir sonucu olarak çeşitli paradigmalarla açıklanmaya çalışılan postmodernizm, kapitalizm eşliğinde gündeme gelen tüketim kültürünün ve aynı zamanda gelişen teknolojik yapının toplumsal, siyasal, ekonomik vb. alanlarda var olan "tahrip edici güç" ilişkisiyle bağdaştırılmaktadır.

Çalıșmada; modernizme ve postmodernizme değinilerek modernlik-postmodernlik ilişkisi ve/veya karşıtlığı göstergebilimsel analiz üzerinden Jean-Luc Godard'ın "Serseri Âşıklar” ve David Lynch'in “Mavi Kadife” filmleri örnekleminde ele alınmıștır. Böylelikle modernlik-postmodernlik bağlamında anlam kazanmış görüşlerin, söz konusu filmler üzerinden değerlendirilmesi yapılmıştır.

\section{1. Özgürlük, Eşitlik ve Kardeşlik: Modernizm}

Tarihsel süreçte yaşanan pek çok olay modernizmin doğuşuna zemin hazırlamıştır. Antik Yunan'da erkek vatandaşların “agora”larda demokratik katılımı sağlamaya çalışması, Helenistik dönemde bireyciliğin ön plana çıkmaya başlaması, Roma döneminde kamu hukuku ve özel hukuk gibi kavramların ortaya çıkması, modernizm süreçleri olarak görülmektedir. Bunlarla birlikte; 11. ve 12. yy'a gelindiğinde feodal düzende kamu ile özel alan arasındaki ayrımın tamamen kalkması, iç içe olması ve 16.yy'da tüccar sınıfının burjuva kamusal alanı hâkimi olması, modernizm sürecine yönelik yaşanacak adımların temeli olarak değerlendirilmesi açısından yanlış sayılmamaktadır.

Modernizmin ortaya çıkmasında etkili olan Rönesans, Reform ve Aydınlanma Çağl birbiriyle paralel gelișen ve birbirini tamamlayan olgular olarak değerlendirilmektedir. Rönesans'ın meydana gelmesinde önemli rol oynayan tüccar sınıfının geleneksel olandan koparak yerine yeni olanı benimseme çabası, özellikle sanat ve edebiyat alanında değişikliklerin yaşanmasını sağlamıştır. Bu döneme eşlik eden Hümanizm ise Faure'ye göre devrimci niteliklere sahip bir terimdir. "Ara-Araştır" kavramı Hümanizm'de slogan olarak kabul edilmiştir $(1995,119)$. 
Ara-Araştır sloganı beraberinde var olan kaynakları sorgulamayı ve onlar üzerinde düşünmeyi ifade etmektedir. Tarihte birçok düşünür söz konusu sloganla hareket ederek işaret edilen kaynakların anlamlandırılmasında öncülük etmiştir. Böylece sosyal, siyasal ya da ekonomik olgular tartışılmaya ve toplum dinamikleri sarsılmaya başlanmıştır. Rönesans ve Reform hareketlerinin yaşandığı Orta Çağ Avrupası'nda birey özgür düşünce sistemini geliştirmeyi başarmış, toplumsal olaylara aklını referans alarak yaklaşmaya başlamıştır. Yaşanan söz konusu süreçlerin de insanlığı Aydınlanma Çağı'na emin adımlarla sürüklediği gerçeği, araştırılması gereken başka bir dönem olarak literatürde yerini almıștır.

Çüçen'in (2006, 31-32) de belirttiği gibi literatürde; akılcılık, bilimcilik, aydınlanmış din, metafiziğin reddi, ilerlemecilik, insancılık, bireycilik, insan hakları ve özgürlük, evrenselcilik başlıkları altında toplanan aydınlanma ilkeleri, aslında Aydınlanma Çağı hakkında temel prensipleri ortaya koymaktadır. Karasar, Aydınlanma'da somut olgular üzerinde durulduğunu ve soyut olanın bilinmezliğinin tartışıldığını belirtmektedir $(2018,5)$.

Aydınlanma Çağı'nın beraberinde getirdiği modernizm, temelinde geleneksel olana karşı duruş sergilemektedir. Aydınlanmayla bireyin aklını aracı olarak kullanması sonucu farkındalık eşiğini yükseltmesi ve yeni olanı keşfetmesi bağlamında ortaya çıkan modernizm Demir'e göre, eski olandan radikal bir şekilde ayrılığı ve yeni olguların kabul edilmesi anlamına gelmektedir (Demir, 2001, 38). Modernizm aydınlanmanın etkisiyle ilerlemeci anlayıșı benimseyerek, ideal toplum düzenine ulaşmaya çalışmaktadır. Ayrıca modernde benimsenen sınıflandırma ve sınıflandırmalara dayanan hak/sorumluluk anlayışları olağan kılınmaya başlanmıştır (Vatandaş, 2015, 315).

Aydınlanmanın etkisiyle rasyonel aklını kullanmaya başlayan modern bireyler, eylemlerde bulunurken, daha özgür alanlara sahip olma amacıyla hareket etmiștir. $\mathrm{Bu}$ yüzden modernizm Bauman’ın da ifade ettiği üzere, “Özgürlük, eşitlik ve kardeșlik" sloganını benimsemiştir $(2003,131)$. Gelenekselden bağlarını koparmayı amaçlayan modernizm kabullendiği yeni sloganla birlikte bireyler üzerindeki etkisini arttırmaya başlamıştır. Bu durum, geleneksel toplumdan modern olan topluma geçişe neden olmuştur. Temelinde geçmiş ya da gelecek hakkında kaygı taşımayan modernizmin modern toplumlarda tek kıstası, şu anda neler olduğu üzerinde gelişmektedir. Jeanniere, modern dünyanın kendisinden daha önce var olmuş hiçbir yapı ile ilişkilendirilemez oluşuna ve onların yerini almaya başlamış olmasına vurgu yapmaktadır $(1994,16)$. Böylece modern toplumlarda bir "modernlik" algısı gelişmeye başlamıştır.

Modernlik terimi ana hatları itibariyle geniş bir perspektifte karşımıza çıkmaktadır. Modernlik, modernizmden bağımsız değildir. Fakat onu modernizmden ince bir çizgiyle ayırmak da oldukça zor bir iş sayılmaktadır. Sarup modernliğin aslında Rönesans döneminde gündeme gelmeye başladığını belirtmektedir. Fakat modernlik, on sekizinci yüzyıldan günümüze kadar gelen sosyo-kültürel, siyasal ve ekonomik alanlarda yer alan kapsamlı bir terim olarak literatürde yerini almaktadır (2010, 184). Modernlik özellikle edebiyat ve sanat alanlarında meşruluğunu ilân etmiştir. Modernizm ile sağlanan geleneksellikten kopuş bilinci modernlik algısıyla sanat ve edebiyat eserlerinde kendisine yer bulmaya başlamıştır. Modernliğin sanat ile bütünleşmesi ve başarı sağlaması ise aslında Berman'ın modernliği tanımladığı 
üçüncü evresinde gerçekleşmektedir (Bkz: Özkiraz, 2003). Özkiraz, üçüncü evre dönemine denk gelen 20. Yüzyılda modernleşmenin küresel boyuta ulaştığını ve modernliğin sanatta yetkinliğe ulaşmaya başlandığını belirtmektedir $(2003,29)$. Bu dönemdeki eserler, eski olan kalıpların yıkılıp yerine "yeni bir şeyler söyleme" fikri üzerinde şekillenmiştir. Edebiyat, resim, müzik, tiyatro, sinema vb. alanlarda etkisini gösteren modernlik, birçok kişi tarafından benimsenmiş ve kabul görmüştür. Eski kalıpların yıkılması modern sanatta önem kazanmıș ve modern niteliklere sahip olamayan yapıtlar geleneksel olarak adlandırılmıștır.

Batı'da yaşanan siyasal, toplumsal ve kültürel dönüşümlerin ortaya çıkarttığı modernizm, bireylere sahip olabilecekleri bir takım imkânları vââd etmektedir. Fakat modernizm vââd ettiği imkânları gerçekleștirememesi konusunda eleştirilmektedir. Modernizm, eleştirdiği “eski" olandan, savunduğu "radikal” kopuşu gerçekleştirirken, aslında kendisinin de eleștirdiği yapılara benzemeye başladı̆̆ tartışılmaktadır. Özellikle kamusal alanın modernizm ile modern kamuya dönüşmesi konusunda Özkiraz, modern kamuda toplu olanın ayrışmasıyla modernlilik fikrinin özünü kaybettiğini ileri sürmektedir. Bu durumda da Berman' a göre bireyler, modern gibi görünen ama aslında modern olmayan toplumsal yapı içerisinde yaşamaktadır $(2003,29)$. Modernizmin savunduğu tek tiplik ve standartlara dayanmaya başlayan kalıplar modernizme ve modernliğe karşı, karşıt görüşlerin gelişmesine neden olmuştur. Kapitalizmin biçimlendirdiği modernizm zamanla özünden uzaklaşmıștır. Kitlelerin daha kolay kontrol edilebilmesine hizmet eden bir yapıya dönüşmüştür. Demirhan, modern toplum için bireylerin sistemler gereğince biçimlendirilmeye çalışıldığı "kafes” benzetmesini kullanmıştır $(1992,62)$.

Modernizm geçmişten kopuşu destekleyerek, ilerlemeci anlayışla ideal bir toplum oluşturma savını benimsemiş olsa da zamanla niteliğinin değişerek, kapital sisteme entegre edildiğini görmekteyiz. Karaduman'ın da belirttiği gibi modernizm; geleneksel ve feodal olanı geride bırakmayı amaçlarken, kapitalizmi benimseyerek alt ve üst yapılarını buna göre de şekillendirmeye başlamıştır $(2010,2289)$. Bu sonuç; modernizmin vââd ettiği daha özgür ve daha eşit yaşam alanlarının modern toplumlarda farklı bir perspektifte vücut bulduğunu ortaya koymaktadır.

Toplumsal yapıda birden fazla alanda hâkimiyet kuran modernizm, sinema alanında da farklılıkları beraberinde getirmiştir. Geleneksel olandan ayrışma, kalıp yargıları yıkma ve yerine modern olanı benimseme uğraşları özellikle Godard sinemasında yer bulmuştur. Modern anlatı ile özdeşleştirilen Serseri Âşıklar filmi, Godard'ın modernizm ile sinemayı birleştirdiği önemli yapıtlar arasında değerlendirilmektedir.

\section{2. Özgürlük, Farklılık ve Hoşgörü: Postmodernizm}

Postmodernizmi tek bir kavram üzerinden açıklamak yetersiz kalmaktadır. $\mathrm{Bu}$ yüzden postmodernizm literatürde farklı şekillerde açıklanmaya çalışılmış fakat kesin bir yargıya ulaşılamamıştır.

Bazılarına göre modernizmin devamı bazılarına göre ise modernizmin reddi olarak açıklanmaya çalışılan postmodernizm için kesin bir tanım bulunmamaktadır. Eskiye dair/eski aşamaya dair her șeyin bittiğini ve yeni bir aşamanın oluştuğunu ileri süren postmodernizm, modern olanın ömrünü tamamladığına işaret etmektedir (Karabulut ve Biricik, 2017,37). Öncelikle sanat dünyasında ortaya çıkmaya başlayan postmodernizm zamanla sınırlarını genişletmeye başlamıştır. "Postmodern" terimi, 
1940’lı ve 1950'li yıllarda yeni mimari ya da şiir biçimlerini betimlemek üzere kullanılmakla birlikte modernizme karşı duruşu açısından 1960'lı yıllara tekâbül ettiği bilinmektedir (Best ve Kellner, 1998, 24). Postmodernizmin nitelikleri bağlamında yaklaşılan kavramsallaştırmalar içerisinde David Harvey'in de görüşü önem taşımaktadır. Harvey, postmodernizmin Baudelaire'in modern anlayışında değindiği geçiçi olma, parçalanmışlık, süreksizlik ve kargaşa gibi unsurlara işaret ettiğini belirtmektedir. Fakat postmodernizm, söz konusu unsurları ne aşmayı ne de ona düşman olmayı benimsemekte, kaotik değişim havuzu içerisinde debelenip durmaktadır $(2012,60)$. Bu noktada postmodernizm ve modernizm konusundaki tartışmalar, temelinde bir kopuşun yaşandığına ya da farklı şekilde eklemlenmiş dinamiklerle devam ettirilmeye çalışan, metamorfoza uğramış modern anlatılar topluluğu çerçevesinden açıklanmaya çalışılmaktadır.

Henüz ortak kertede buluşulamayan modernizm ve postmodernizm üzerinden toplum nitelemeleri de yapılmaya başlanmıştır. Özellikle çoğu uzman ve akademisyen tarafından günümüz toplumları "postmodern toplum" olarak nitelendirilmektedir. Terim olarak geniş kapsamda ele alınan postmodernizm; epistemoloji, metodoloji ve ontoloji yapılarını özünde bulundurarak kültürel ve politik oluşumları beslemektedir (Demir, 2001, 45). Farklı oluşumları özünde barındıran postmodernizm hakkında literatüre önemli katkılar sağlayan Lyotard, Derrida, Baudrillard vb. gibi düşünürler, modernizmin getirdiği sorunlara değinirken, postmodernizm ve modernizm arasındaki çıkmazları da ele almışlardır.

Postmodernizm üzerine çalışmalar yapan Baudrillard, postmodernizmde var olan durumlara işaret etmiştir. Modern dönemden farklı bir üslup belirleyen postmodernizm; özellikle sosyal tutarlılık ve nedensellik yapılarının modern dönemde ait olduğu özünü; çokluk, çoğulluk ve belirsizlik uğruna kabul etmemeyi tercih etmektedir (https://pages.gseis.ucla.edu/). Postmodernizm'de tek bir gerçeklik bulunmamaktadır. Gerçekliğin birden fazla görünümü ya da yansıması olabilmektedir. Sürekli bir düzensizlik, çoğulculuk ve zamanda süreksizlik bulunmaktadır. Bunun sonucunda postmodern dönem insanı, yeni medya olanakları ile gerçek olmayan bir evrenle sarmalanmış ve bu evreni gerçekmiş gibi kanıksamaktadır. Kısacası, içi boşaltılmış bir dünya düzeni postmodern dönemde anlamlıymış gibi kılınabilmektedir. Baudrillard, günümüz toplumlarında gerçekliğin olmadığını bunun yerine hipergerçeklik ya da simülasyon ile gerçeklerin yeniden üretildiğini belirtmektedir $(2011,14)$. Gerçek- yapay arasındaki farkı çözemeyen birey ise kendi iç dünyasına dönmek durumunda kalmaktadır. Postmodern anlayışın temelinde aslında anlamların var olmadığına değinen Baudrillard, anlamın giderek anlamsıza dönüştügünü ve toplumsal olanın da sona gelmeye bașladığına işaret etmektedir. Toplumsal olanın sonunun gelmesiyle birlikte pek çok şeyin de anlamsızlaşması, aslında modernden kopuşu ve eleştirileri beraberinde getirmiştir.

Postmodernizm'de karşımıza çıkan bir diğer isim Derrida'dır. Yapısöküm tarihinin eskilere kadar uzandığını ifade eden Derrida, aynı zamanda bu sürecin günlük kullandığımız dilin en derinine kadar da işlediğini belirtmektedir $(2001,351)$. Dilin sabit anlamlar dizgesinde yer almadığını, değişen sistemler içerisinde de olabileceğini savunan Derrida, postmodernizmde var olan nesnellik eleştirisi ile yola çıkarak dilin değerlendirilmesi gerektiğini vurgulamaktadır. Buna göre, postmodern dönemde eleştirilen nesnelliğin metinlere de uygulanması gerekmektedir. Derrida bu sayede metinleri okumayı olanaksız kılma amacı gütmeye çalışmaktadır (Hoy, 
2007, 56). Bunun bir sonucu olarak postmodern dünyada gerçeğe ulaşmanın yolu, sürekli bir arayış içerisinde olarak görülmeyeni görmeye çalışmak, şeklinde değerlendirilebilmektedir.

Lyotard, postmodernizm ve üst anlatı ilişkisi bağlamında anlayışların değişmesine vurgu yapmaktadır. Modernizmde bulunan eșitlik, evrenselcilik vb. gibi üst anlatılar postmodernizmde değișerek anlamını yitirmektedir. Büyük anlatıların sonunun gelmesiyle birlikte yeniden, yeni üst anlatılar oluşturmak postmodernizmde var olan çoğulculuk anlayıșı ile pek de kolay gözükmemektedir. Bu yüzden Lyotard, postmodernizmi büyük anlatılara karşı inanmamazlık durumu olarak tanımlamaktadır. Bu inanmamazlık ise bilimin sahip olduğu ilerlemeci anlayıștan ortaya çıkmaktadır (Lyotard, 1994, 12). Lyotard, postmodernizmde bulunan nesnelliğin eleştirisine karşı kuşkucu bir yaklaşım sergilemektedir. Şaylan'ın da belirttiği üzere Lyotard, nesnel olana eleștirinin yanı sıra bilgi edinme esnasında metin teriminde farklı niteliklerin (fotoğraf, kişisel istek, eğilimler vs.) de rol oynadığını savunmaktadır (1999, 229-230). Buna göre tek bir anlam dizgesine oturmayan metin terimi; hem içerisinde bulundurduğu özelliklerle hem de bireylerin sahip olduğu ya da istedikleri şeylerle paralel olan ve bir o kadar da karmaşık yapıya işaret etmektedir.

Sahip olduğu olgularla birlikte genellikle modernizme yöneltilen eleştirileri bünyesinde barındıran postmodernizm, Bauman'ın da belirttiği gibi modernizmde var olan belirsiz koşullara karşı durmuş ve tekliği eleştirmiştir. Kalıplaşmış modern yargıları ters yüz etmeyi amaçlayan postmodernizm; özgürlük, farklılık ve hoşgörüyü benimsemiştir (2003, 131). Postmodernizm teklik karşısında çoğulculuğu, farklılığı ve aynı zamanda bireyin modern olandan bağımsızlaşarak özgürleşmesini savunmaktadır. Kültür, sanat, siyaset, ekonomi vb. birçok alanda bireyin modern olandan özgür olma düşüncesinin yaygınlaşması, tek tipliğin bireysel olana tercih edilmesi postmodernizmin bireyler arasında kabul görülmesini de kolaylaștırmıștır. Postmodernizm anlayıșı temelinde modernizmin getirdiği ideal dünya anlayıșını eleştirmekte ve bunu yaparken de gerekçelere dayandırmaktadır. Örneğin, Horkheimer ve Adorno; modernizmde kitlelerin atomize edilerek, birbirinden yalıtıldığını ve böylelikle bireylerin daha kolay etki altına alınıp, yönlendirilebildiğini ifade etmektedir $(1996,166)$.

Diğer alanlarda olduğu kadar sanatta da kendisine gelişme imkânı bulan postmodernizm, modernizmden farklı ilkeleri benimsemiştir. Var olan bir anlatının anlamını değiştirerek yeni bir bakış açısıyla hem eskiyi sorgulayan hem de alternatifler üreten postmodernizm, sanat ve edebiyat gibi pek çok alanı etkisi altına almıştır. Postmodernizm'de vurgu biçemle kullanılmaya başlanmıştır, gerçeklik imgesel anlamına bürünmüştür ve zaman şimdinin içerisinde parçalanarak anlatım sağlanmıştır (Sarup, 2010, 187). Bu durum özellikle sinemada postmodern anlatıda David Lycnh filmlerinde, alışılagelmiş durum ya da olguların hemen ardından yeni bir paradigma yaratmasıyla bilinmektedir. Onun bu anlatımını destekleyen filmlerinden birisi olan "Mavi Kadife" ise postmodern sinemanın örneklerinden birisini oluşturmaktadır.

\section{Analizler}

Modernizm ve postmodernizm ilişkisinin ve/veya karşıtlığının ele alındığı çalışmada göstergebilimsel analiz kullanılmıştır. Sassure, Pierce, Strauss, Baudrilliard, Barthes 
ve Kristeva vb. gibi isimler göstergebilim üzerine çalışmalar yapmıştır. Söz konusu isimler yaptıkları çalışmalar ve sahip oldukları yaklaşımlarla göstergebilimle katkı sağlamışlardır.

Çalışma Roland Barthes'ın görüşleri perspektifinde ele alınmıştır. Bu yüzden konudan sapmamak için Barthes'ın görüşü hakkında kısaca bilgi vermek açıklayıcı olacaktır. Barthes $(1979,2)$ göstergebilime; dil-söz, gösteren-gösterilen, dizge-dizin, yananlam-düzanlam, ilișkisinde yaklaşmıștır. Ona göre, göstergenin temsil ettiği şey düz anlam, göstergenin nasıl temsil edildiği ise yan anlama işaret etmektedir. Kavramlar ise gösterenlerdir. Bunlar da zihnimizde gerçek dünyanın soyutlanmış imgelerine denk düşmektedir. Ayrıca çalışmalarında üstdil kavramına yer veren Barthes, göstergebilimin üstdil olduğuna işaret etmektedir. "Çünkü göstergebilimde incelenen dizge olan birinci dili, ikinci bir dizge olarak üstlenmektedir" $(1979,90)$.

Göstergebilimsel analiz ile metinlerin içerisinde yer alan düz anlamlar ve yan anlamlar çözümlenmekte, metinlerin ardılında yatan gerçekler dizgeler ile ortaya çıkarılmaktadır. Çalışmada kullanılan göstergebilimsel analiz ile modern anlatı sinemasında yer alan Jean-Luc Godard'ın "Serseri Âşıklar" filmi ve postmodern anlatı sinemasında yer alan David Lynch'in "Mavi Kadife" filmi değerlendirme kapsamına alınmıştır. Böylelikle söz konusu filmler üzerinden modernizm ve postmodernizm örneklendirilmeye çalıșılmıştır. Ek olarak filmlerdeki veri yoğunluğu nedeniyle, her iki filmde kendi içerisinde yer alan ilk 15 dakikasında bulunan kesitler ile sınırlandırılmış ve analizleri yapılmıștır.

\subsection{Jean-Luc Godard: Serseri Âşıklar}

1960 yapımı Godard filmi olan Serseri Âșıklar, sinemada klasik dönemin bittiğinin habercisi niteliğini taşımaktadır. Yeni Dalga'nın egemen olduğu filmde klasik anlatıda yer alan unsurların Godard tarafından kullanılmaması, çekim tekniğinde ve oyuncu yönetiminde farklı, yeni bir üslup benimsenmesi önem taşımaktadır. Doğaçlamanın ön plana çıkarıldığı filmde yönetmen, iç mekânlardan daha fazla olarak sokağı kullanmış ve doğal ışığı tercih etmiştir. Film, erkek karakterin (Michel) araba çalması ve sonrasından yolda bir polisi öldürmesini, ardından da Patrica adında genç bir kadınla kaçışını konu almaktadır. Birbirini izleyen olaylar arasındaki bağlantı hızlı ve sık geçişlerle sağlanmıştır. Ayrıca Klasik anlatıda olan çember şeklinde açılankapanan geçişlerin yerini Godard sinemasında kararma ve açılma efektleri almıştır. Çalışmada söz konusu filmin ilk 15 dakikası ele alınmış ve incelenmiştir.

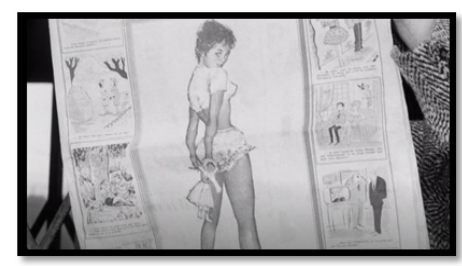

Kesit 1

Filmin ilk karesi, gazetedeki kadın gösterimi ile açılmaktadır. Gazetenin kenarlarında bulunan sütunlarda, küçük görsellerle farklı konulara dikkat çekilmeye çalışılırken aslında odak nokta, gazetenin tam ortasında bulunan kadın imajına kaymaktadır. Bu sahnede kadın temsiliyetine vurgu yapılmıștır. Görüntüye eşlik eden konuşma ise filmin erkek karakterine aittir. Görüntü akarken erkek karakterin (Michel) "Aslında enayinin biriyim, aslında evet öyle olmalı. Öyle olmalı!” dedikten sonra 
gazeteyi katlama sahnesine geçilmektedir. Burada gazetedeki kadın temsiliyeti vurgulanırken, bir yandan da erkek karakterin (Michel) sözlerine devam etmesi, erkek karakterin genel olarak aslında kadınlara olan ilgisine gönderme yapılmıștır, şeklinde yorumlanabilmektedir.

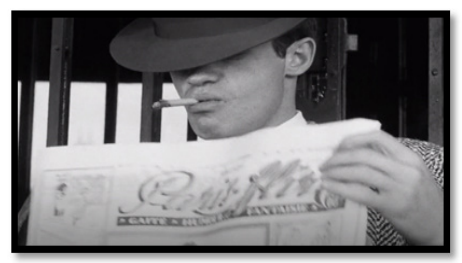

Kesit 2

Film 00.44 saniye içerisindeyken, erkek karakterin (Michel) yüzünü kadrajda görmeye başlarız. Fötr şapka takan karakterin aynı zamanda sigara içtiği de gözlerden kaçmamaktadır. Burada modern çağın modern erkeğinin modern giysi seçimi dikkat çekmektedir.

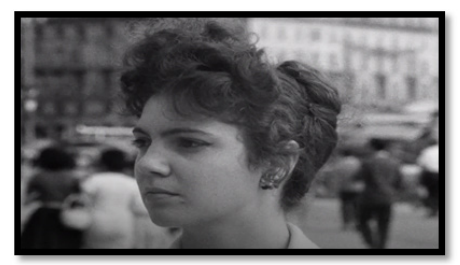

Kesit 3

00.58'de erkek karakterden (Michel) farklı olarak kadraja bu sefer kadın karakter girmektedir. Filmin ilk sahnesinde temsil edilen kadın ile 00.58'de temsil edilen kadın arasında farklar görülmektedir. "Modern" ve "şehirli" algılarının oluşturulmaya çalışıldığı filmde kadın, mekân olarak sokakta gösterilmektedir. Yine burada kadının başka bir temsiliyeti söz konusudur.

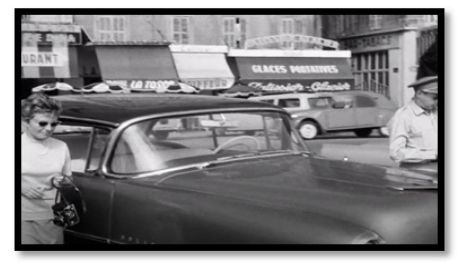

Kesit 4

Filmin 01'17" de sokaktaki başka insanlar üzerinden sahne çekilmiștir. Arabadan inen çift görüntülenirken yine burada şehirli ve modern algıları oluşturulmuştur.

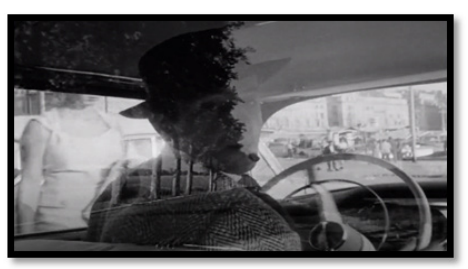

Kesit 5

02'00" da klasik anlatıda var olan kalıpların dışına çıkılarak bir çemberin açılması ya da kapanması şeklinde gerçekleştirilen sahne geçişlerinin artık, açılma ve kararma ile sağlandığını görebiliriz. Godard burada modern anlatı ve Yeni Dalga'nın beraberinde getirdiği nitelikleri sonuna kadar kullanarak izleyiciyle paylaşmıștır. 


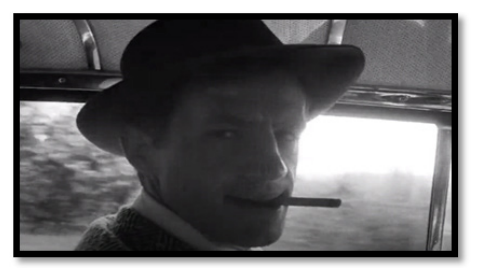

Kesit 6

03' 12" de filmin temelini oluşturan Yeni Dalga ve modern anlatının giderek baskın olmaya başladığı görülmektedir. Çünkü Godard bu sahnede, klasik anlatıda olmayan başka bir tekniği kullanmıştır. Oyuncunun kameraya bakarak konuşması izleyici ve film arasındaki bağın koparılması adına büyük önem taşımaktadır. Görüntü akarken erkek karakterin (Michel) sanki karşısında kamera değil de bir kişi varmışçasına konuşması dikkat çekmektedir. "Denizi sevmiyorsanız, dağları sevmiyorsanız, şehri sevmiyorsanız, canınız cehenneme!" diyerek bir nevî izleyiciye seslenmiştir. Buradaki amaç, izleyicinin filmin içerisinde olduğunun unutturulmamasıdır.

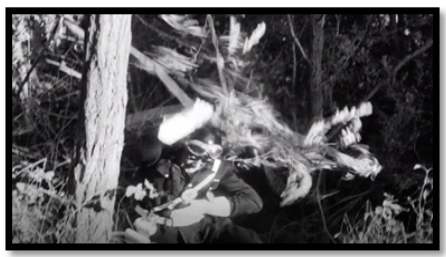

Kesit 7

Filmde erkek karakterin (Michel) bir polisi vurduğunu ve onu öldürdügünü görürüz. Öncelikle erkek karakterin sağ tarafının yakın çekim yapılarak yüz, kol ve en son silahın ucunun kadrajda gösterilerek polise doğru ateşlenmesi ve hemen ardından çalıların arasına düşen polisin ölümü bu sahnede gösterilmiștir.

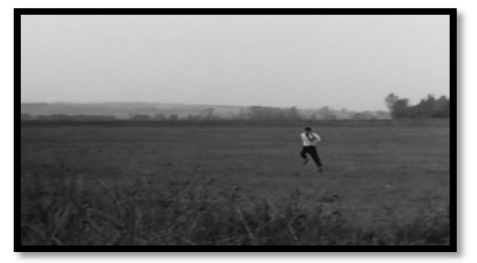

Kesit 8

Sahne 05’30" bağlı olarak gelişen sahne 05'33"' de erkek karakterin (Michel) polisi öldürmesinin ardından boş bir arazide koşması/kaçması gösterilmiştir. Godard burada genel çekim kullanarak işlenen bir suçun ardından modern bireyin nasıl tepki verdiğini göstermiştir.

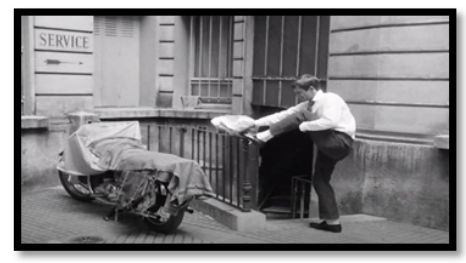

Kesit 9

Burada Godard eski olana, kalıplaşmış olana gazete üzerinden gönderme yapmıştır. $\mathrm{Bu}$ sahnede erkek karakterin gazeteyi alıp okumasından hemen sonra ayakkabı sileceği olarak kullanması aslında yönetmenin eski olan ne varsa kullanıldıktan sonra artık bir kenara atıldı, demesinin göstergesi sayılabilmektedir. 


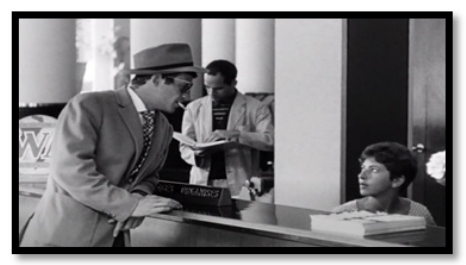

Kesit 10

Godard, Serseri Âşıklar filminde kurguya oldukça önem vermiştir. Karakterlerin yaptıkları hareketler ve davranıșlar sık kesmelere dayandırılmıștır. Bir sahneden diğerine hızlı bir şekilde geçilmiştir. Bunun da en iyi örneğini filmin 09'56" sahne açılma efekti açıldıktan sonra erkek karakterin (Michel) Bay Tolmachov'u çalışan bir kadına sorduğunu görmekteyiz. Bu sahneden erkek karakterin nereye geldiği, nasıl geldiği, neden Tolmachov'u sorduğu açıkça belli edilmemiştir.

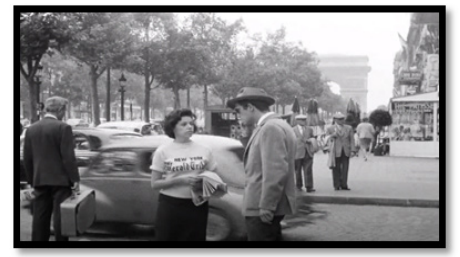

Kesit 11

09'56" daki sahnede erkek karakterin Bay Tolmachov'u sormasının ardından, 10'01" de sokak sahnesine geçilmiş ve bu sefer orada Patricia adında birisini başka bir kadına sorduğunu görmekteyiz. İki sahne arasındaki bağlantıyı kurmakta güçlük çeken izleyici alışılagelmiş kurgu ritmini yakalayamamaktadır. Film; Tolmachov ve Patricia'nın kim olduğunu ve erkek karakterin (Michel) onları neden aradığının cevaplarını ilerleyen dakikalarda izleyiciye sunacaktır.

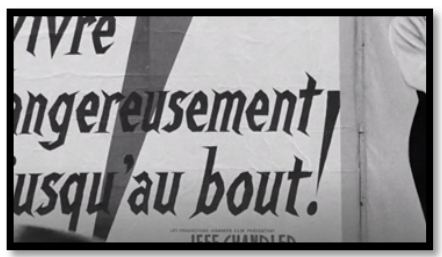

Kesit 12

13'17" de “Tehlike İçinde Sonuna Kadar YAŞAMAK!"yazan bir afiş gösterilmekte ve hemen ardından erkek karakterin (Michel) yürürken görüntüsü verilmektedir. $\mathrm{Bu}$ sahnede erkek karakterin işlediği suç sonrasında tehlike içinde olduğuna ve kanundan kaçarak bir şekilde yaşamaya çalışmasına vurgu yapılmaktadır.
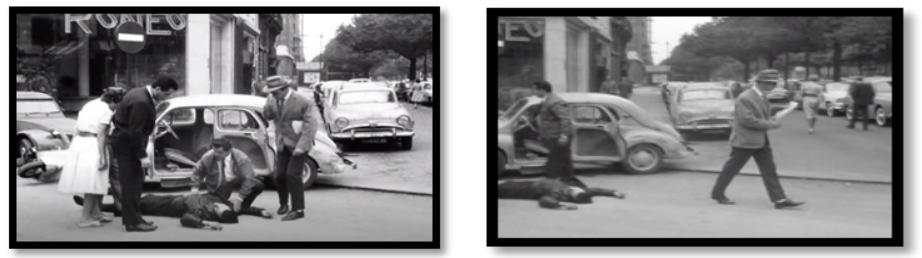

Kesit 13/14

Aynı sahnede yer alan 13'41" ve 13'43" de bir kaza sonucu yere düşen birisini görmekteyiz. Erkek karakterin olaya yakından bakması ve sigara içmeye devam etmesi ise suçlu kendisi olmadığı için rahat bir tavır takındığı, şeklinde yorumlanabilinir. 
Godard modern anlatıda yer alan Serseri Âşıklar filminde, modern karakterin verdiği tepkileri iki farklı sahnede işleyerek karşılaştırmıştır (Bkz: Kesit 8).
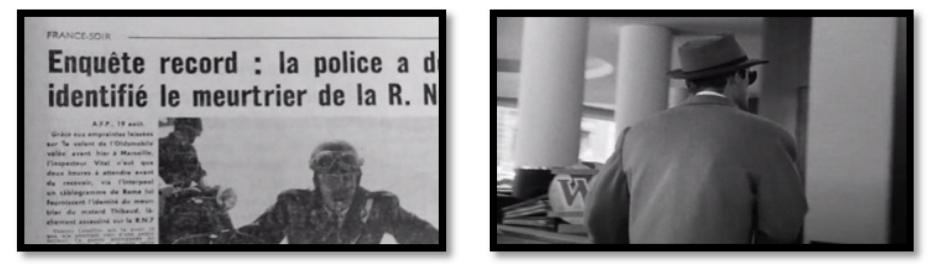

Kesit 15/16

Kazanın ardından elinde gazetesi ve ağzında sigarası olan erkek karakter (Michel) rahat bir şekilde yolda ilerlerken, gazetenin sayfasını açmasıyla kendisinin öldürüğü polis hakkında haberle karşılaşır. Haberde "Polis Cinayetin Failini Belirledi!" başlığı ile karşılaşan erkek karakter, yine aynı iş yerine gelerek Bay Tolmachov'u tekrardan sormaya başlar.

Tablo 1: Serseri Âşılklar Filmi Görüntüsel Gösterge Anlam Tablosu

\begin{tabular}{|c|c|c|c|}
\hline \multicolumn{4}{|c|}{ Görüntüsel Gösterge } \\
\hline \multirow{2}{*}{ Gösterenler } & \multirow{2}{*}{ Sahne Sayısı } & \multicolumn{2}{|c|}{ Gösterilenler } \\
\hline & & Düz Anlam & Yan Anlam \\
\hline Kadın & 32 & İnsan & $\begin{array}{l}\text { Modernlik, Cinsellik, } \\
\text { Şehirleşme }\end{array}$ \\
\hline Gazete & 10 & Nesne & $\begin{array}{c}\text { Haber Edinme, Eskiye } \\
\text { Vurgu Yapma }\end{array}$ \\
\hline Erkek & 55 & İnsan & Modernlik, İktidar, Serseri \\
\hline Sigara & 23 & Nesne & Modernlik, Erkek, Statü \\
\hline Fötr Şapka & 24 & Aksesuar & Modernlik, Erkek \\
\hline Gözlük & 6 & Aksesuar & Modernlik, Erkek, Kadın \\
\hline Araba & 27 & Araç & Modernlik, Zenginlik \\
\hline Cadde/Yol/Sokak & 37 & Cadde/Yol/Sokak & Modern Anlatı Mekanı \\
\hline Polis & 8 & İnsan & Kolluk Kuvveti \\
\hline Silah & 2 & Eşya & Güç, Suç, Erkek \\
\hline İç Mekan & 8 & İç Mekan & İç Mekan \\
\hline Dergi & 2 & Nesne & Kadın, Magazin \\
\hline Para & 3 & Nesne & Zenginlik- Kadın, Fakirlik- Erkek \\
\hline Afiş & 11 & Nesne & Reklam, Kadın \\
\hline Ayna & 7 & Eşya & $\begin{array}{l}\text { Kadın-Güzellik, Erkek- İç } \\
\text { Dünyanın Sorgulanması }\end{array}$ \\
\hline
\end{tabular}

\subsection{David Lynch: Mavi Kadife}

1986 yapımı David Lycnh filmi olan Mavi Kadife, Postmodern anlatı sinemasının en önemli yapıtlarından birisi sayılmaktadır. Modernliğin ne inkâr edildiği ne de taklit edildiği postmodern gelenek anlayıșını Lynch, filmlerinde başarılı bir şekilde kullanmıştır. Evinden uzakta olan Jeffrey'in babasının kalp krizi geçirdiği haberini almasıyla ailesinin yaşadığı kasabaya gelmesi ve yolda sahibi belli olmayan kesik bir kulak bulması filmin konusunu oluşturmaktadır. Postmodern anlatının 
sahip olduğu düzensizlik ve süreksizlik anlayışı filmde sahneler arası geçişlerde kendisini göstermektedir. Rahatsız edici derece yakın çekim tekniğinin kullanılması, karakterlerin bir olaya son noktayı koymaması, zamanın belirsiz olması ve gerçekliğin başka bir olayla belirsiz duruma getirilmesi postmodern anlatıyı kapsamaktadır. Çalışmada söz konusu filmin ilk 15 dakikası ele alınmış ve incelenmiştir

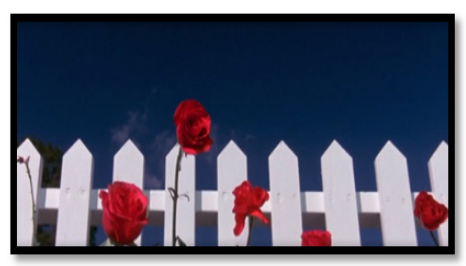

Kesit 1

Film 01'58" da gökyüzü ve kırmızı gül ile açılmaktadır. Lynch, burada filmin geçtiği kasabanın sakin tarafını izleyiciyle paylaşmaya başlamaktadır.

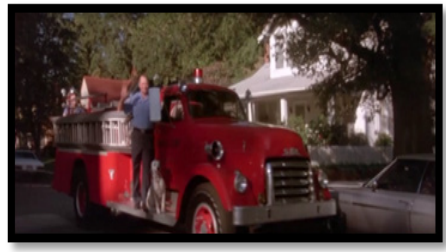

Kesit 2

Modern Anlatı'da Godard'ın kullandığı bir teknik olan oyuncunun kameraya doğru bakması, 02'08" da Lynch tarafından da kullanıldığını görmekteyiz. Burada modern olana yapılan bir selamla ile artık modern olanın devrinin geçtiğinin simgeleştirilmesi yapılmıştır.
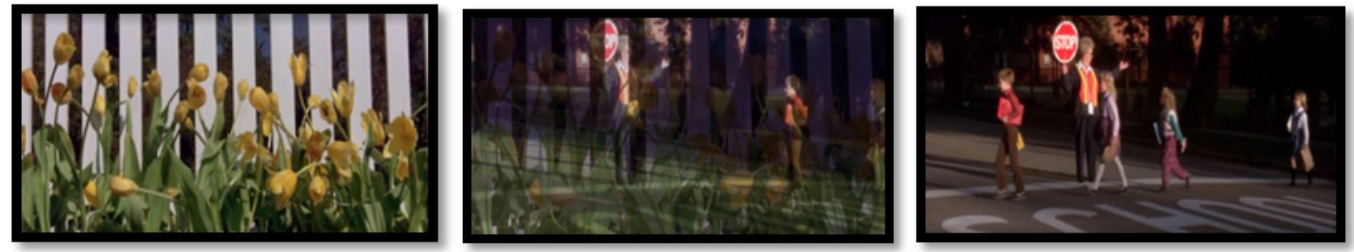

Kesit 3 / Kesit 4 / Kesit 5

Kesit 3, Kesit 4 ve Kesit 5; 02'19" da yine modern sinemada Godard'ın sahne arası geçişlerde kullandığı kararma ve açılma tekniği Lynch tarafından da kullanılarak iki ayrı sahne birbirine bağlanmıştır.
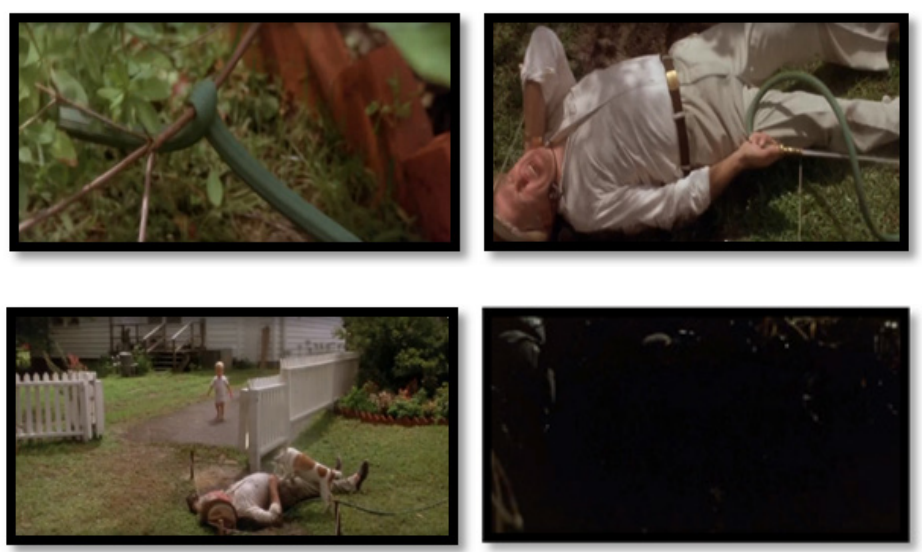

Kesit 6 / Kesit 7 / Kesit 8 / Kesit 9 
Mavi Kadife filminde Lynch, 02'53" dan itibaren bahçe hortumunun sıkışmaya başlamasıyla birlikte, yaşanacak olan talihsiz bir durumu izleyiciye yavaş yavaş betimleme çabasına girmiştir. Güzel bir günde bahçesini sulayan erkek karakterin (baba) geçirdiği kalp krizi izleyiciye gösterilmiştir. Postmodern geleneğin hâkim olduğu filmde yaşanan kötü bir olayın hemen ardından gösterilen sahneler, yaşanan olayı normal olana indirgenmiştir. Köpeğin erkek karakterin (baba) elindeki hortumdan su içmesi, bebeğin bahçede gezinmesi kalp krizi olayını izleyicinin gözünde sıradanlaştırmaya çalışmıştır. Daha sonra yer altındaki böcek yuvasının yakın çekim tekniği ile gösterilmesiyle de Lynch, izleyicinin bağlamdan kopmasını sağlayarak, modern anlatıdaki süreklilik zincirini kırmıştır.

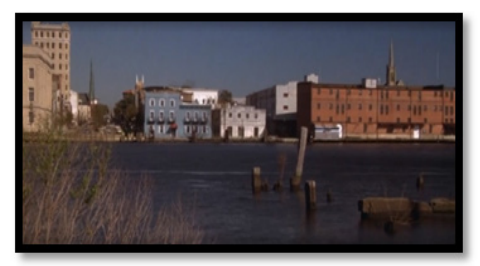

Kesit 10

Süreklilik algısının kırıldığı filmde, Lynch böceklerin gösterildiği kaotik sahneden sonra kasabanın sakin yapısına tekrar vurgu yapmaktadır. Burada tekrardan gündelik hayat normal akışındaymış gibi verilmektedir.

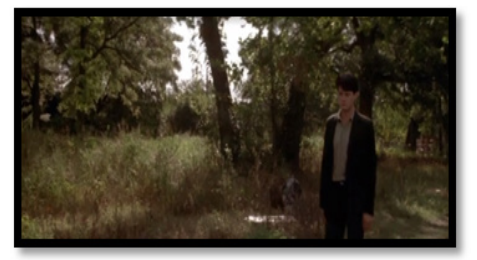

Kesit 11

04'11" da izleyici filmin başrolde olan erkek karakter Jeffrey ile tanışır. Zaman algısında tutarlılık bulunmayan filmde geçmiş, gelecek ve şimdiki zaman arasındaki ayrım kesin değildir. Karakterlerin giysilerinden, kullanılan mekânlardan ya da eşyalardan filmin zamanını anlamaya çalışsak da tam olarak zamanı kavrayamayız. Modern anlatıdan farklı olarak fötr şapka kullanmayan erkek karakterin (Jeffrey), hangi zamanda yaşadığına dair kesin bir çıkarımda bulunulamamaktadır.
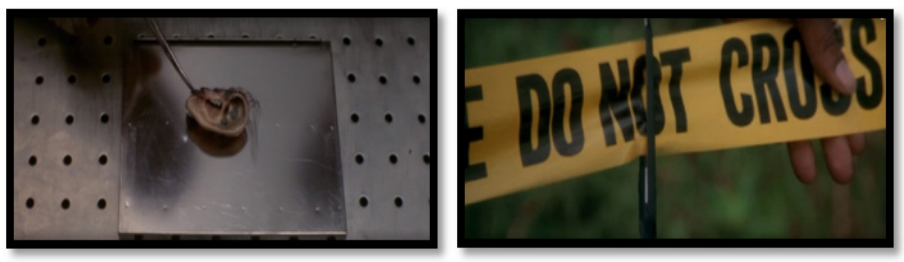

Kesit 12 / Kesit 13

Filmde Jeffrey tarafından bulunan kulağın incelemesinde uzmanın, "Kulak bir makasla koparılmış gibi duruyor." demesi ve ardından polislerin olay yerinde inceleme yaparken kullandığı şerit bantların makasla kesildiği görüntünün gösterilmesi, söz konusu iki sahne arasında kurulan metaforik anlama işaret etmektedir. 

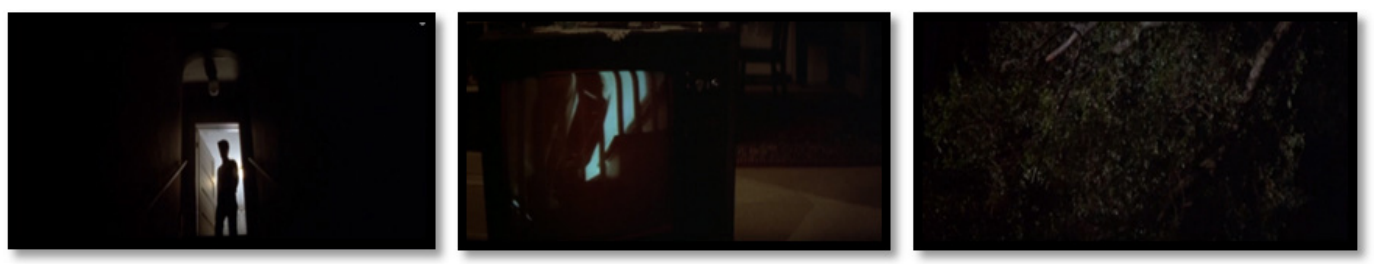

\section{Kesit 14 / Kesit 15 / Kesit 16}

Kulağın Jeffrey tarafından bulunmasının ardından, yaşanacak olan karmaşık olayların habercisi niteliğindeki 09'15" sahne dikkat çekmektedir. Jeffrey'in artık karanlık ve belirsiz bir yola girmek üzere olduğu 09'15"daki görüntüyle anlatılmaya çalıșılmıștır. Bu sahneyi takîben televizyondan kameraya yansıyan merdivenlerden yukarı doğru çıkan başka bir erkeğin görüntüsüyle de Jeffrey'in içinde bulunduğu durum hakkında izleyicide kafa karışıklığı yaratılmak istenmiştir. Daha sonra gökyüzü sahnesi planda gözükmektedir. Gökyüzü filmin başında olduğu gibi açık ve net görülmemekte aksine karanlık ve ağaç dallarından belirsiz bir biçimde gösterilmeye çalıșılmıștır.

Tablo 2: Mavi Kadife Görüntüsel Gösterge Anlam Tablosu

\begin{tabular}{|c|c|c|c|}
\hline \multicolumn{4}{|c|}{ Görüntüsel Gösterge } \\
\hline \multirow{2}{*}{ Gösterenler } & \multirow{2}{*}{ Sahne Sayısı } & \multicolumn{2}{|c|}{ Gösterilenler } \\
\hline & & Düz Anlam & Yan Anlam \\
\hline Gökyüzü & 3 & Gökyüzü & Sakinlik \\
\hline Çiçek & 2 & Bitki & Güzel/Olumlu Duygu Uyandırma \\
\hline Erkek & 33 & İnsan & Olayı Çözme Sürecindeki Eleman \\
\hline Köpek & 3 & Hayvan & Oyuncu, Sevecen \\
\hline Araba & 5 & Araç & Modernlik, Serserilik \\
\hline Kadın & 19 & İnsan & Modernlik, Ev Hanımı \\
\hline Çocuk & 2 & İnsan & İnsan \\
\hline Bina & 10 & Bina & Bina \\
\hline Televizyon & 2 & Eşya & Dizi/Film İzleme Aracı \\
\hline Gözlük & 2 & Aksesuar & $\begin{array}{l}\text { Modernlik, Erkeklik, } \\
\text { Görme Engelli }\end{array}$ \\
\hline Şapka & 1 & Aksesuar & Modernlik \\
\hline Böcek & 2 & Hayvan & Metafor \\
\hline Billboard & 1 & Nesne & Reklam \\
\hline Cadde/Yol/Sokak & 14 & Cadde/Yol/Sokak & Olayların Konuşulduğu Yer \\
\hline İç Mekan & 8 & İç Mekan & Olayların Konuşulduğu Yer \\
\hline Kulak & 4 & Organ & Delil/Kanıt \\
\hline Dedektif & 2 & İnsan & $\begin{array}{l}\text { Olayı Çözmek için } \\
\text { Başvurulan Kişi }\end{array}$ \\
\hline Makas & 1 & Eşya & Metafor/ Eşya \\
\hline Merdiven & 2 & Nesne & Metafor/Nesne \\
\hline Fotoğraf & 1 & Nesne & Kadın, Simge \\
\hline Sigara & 1 & Nesne & $\begin{array}{l}\text { Bunaltıcı İşte Çalışanların } \\
\text { Kullandığı Nesne }\end{array}$ \\
\hline Silah & 4 & Nesne & Güç, Belirsizlik \\
\hline Tabela & 1 & Nesne & Konum \\
\hline
\end{tabular}




\section{Bulgular}

Çalışmada modernizm ve modernlik kıstasında ele alınan "Serseri Âşıklar" filmi, modernizmin sinemada yansıması şeklinde değerlendirilmektedir. İlk 15 dakikası incelenen filmin karakterler, mekân, zaman, çekim, kurgu vb. özellikler üzerinden değerlendirilmesi ve anlamlandırması yapılmıştır. Modernizmle değişen sosyal ilişkiler, toplumsal durumlar, bireysel yönelimler ve temsiliyetlerdeki farklılaşmaların yansıması, sinema alanına da sıçramıştır. İncelemede değinilen Kesit 1'de gazete sayfası üzerinde kadın figürü gösterilmiștir. Bu gösterim sinemada kadının temsiliyetini açık bir şekilde belirtmektedir. Hemen ardından Kesit 3'te baş plan ile başka bir kadın gösterilmiştir. Bu durum modern kadının sinemada ne şekilde temsil edildiğini ve farklıkları üzerinde durulması gerektiğini hatırlatmaktadır. Üstelik filmin ilk 15 dakikasında kadın 32 kere sahnelenirken, erkek 55 kere sahnelenmiş ve kadın ikincil olarak gösterilmiştir. Ontoloji, pozitivizm, feminizm vb. yapıları bünyesinde barındıran modernizmi söz konusu film üzerinden toplumsal cinsiyet bağlamında ayrıca değerlendirmek de gerekmektedir.

Modernizmin etkili olduğu dönemde sosyo-kültürel alanda sigaranın ve fötr şapkanın modernlik sayıldığı, hatta çoğu zaman statüyü gösteren temsiliyetlerden olduğu varsayılmaktadır. Bu sebeple filmde incelenen sahnelerde özellikle dikkat çeken ayrıntı; erkek, fötr şapka ve sigara üçlüsünün yoğunluklu olarak kullanılmasıdır. Filmde erkek 55, fötr şapka 24 ve sigara 23 kez sahnelenmiştir. İncelenen ilk 15 dakika boyunca söz konusu unsurların ardı ardına ya da bir bütün şeklinde ele alındığı anlaşılmıştır. Klasik olandan kopuş ve yeni kalıpların benimsenmesi idealini savunan modernizm, sinemada kurgu ve çekim tekniklerini de ayrıca etkilemiştir. Serseri Âşıklar filminde yönetmen, klasik anlatıda sahne geçişlerinde sıklıkla kullanılan çember biçimindeki açılma kapanma efektleri yerine kararma ve açılma efektlerini benimsemiştir. Analiz içerisinde Kesit 5 'te sunulan bu geçiş, modernizmle birlikte artık klasik anlatıda yer alan biçimlerin değiştiğinin habercisi sayılmaktadır. Modernizmle modern anlatıda kabul gören bir diğer yenilik, Godard'ın sinemaya kazandırdığı oyuncu-sahne-kamera üçlemesidir. Sahne gereği oyuncunun kameraya bakıp konuşması ve rolünü yapması, izleyiciyle film arasında yabancılık sağlanması açısından önem taşımaktadır. Kesit 6'da gösterilen bu yenilik, klasik anlatıda var olan film-izleyici özdeşleşmesine karşı bir duruş sergilemektedir. Yine filmde klasik anlatıda yer almayan ama modern anlatıda sürekli kullanılan özellik, mekân ve oyuncu seçiminde kendisini göstermektedir. Modern anlatıda sokak çekimlerine ağırlık verilmiş ve doğal ıșık kullanılmıștır. Filmin ilk 15 dakikasında 37 kez sahnelenen cadde/yol/sokak Godard'ın Serseri Âşıklar filminde çekimlerin yapılması için tercih ettiği mekânlardan sayılmaktadır. Buna karşılık filmin ilk 15 dakikasında iç mekân sadece 8 kez kullanılmıştır. Ayrıca modernliğin belirli bir kıstası sayılan araba filmin ilk 15 dakikasında 27 kere sahnelenmiștir. Kesit 7 ve Kesit 8 modernizm içerisinde yaşanan bir olayın ardıllarını anlamak açısından değerlendirilebilmektedir. Erkek karakterin (Michel) polisi öldürmesi üzerine olay yerinden kaçarak uzaklaşmasının sahnelendiği Kesit 7 ve Kesit 8'de modern insanın yaşanan durumlara karşı verdiği tepki anlatılmaya çalışılmıştır. Buna karşılık Kesit 13'te genel plan ile bir kaza sonucu yere düşen bir kişi sahnelenmiştir. Hemen ardından gelen Kesit 14'te ise modern erkek karakterin (Michel) olayı meydana getiren unsur ya da kişi olmadığı için daha rahat bir tavırda hareket ettiğini görmekteyiz. Söz konusu 4 sahne bize aslında modern insanın kendisinin sebep olduğu durumlarla suçluluk hissederek arkasına bakmadan kaçabileceğini, fakat bunun tam tersi durum olduğunda yani 
kişinin kendisinin suçlu olmadığı durumlarda ise olaylara karşı kayıtsız bir tavır sergileyebileceğini anlatmaktadır. Aynı zamanda Kesit 9'da modern dönemde televizyonun yaygınlaşmaya başlaması ile gazete arasında metaforik anlam yakalanarak, klasik anlatı ile modern anlatı arasında bağlantı kurulmaya çalışılmıștır. Michel'in gazeteyle ayakkabısını silmesi eski olana yapılan bir gönderme olarak değerlendirilmiştir. Bunun sonucunda klasik anlatının da kullanılıp bir kenara atıldığı, artık modern anlatının var olduğu anlatılmak istenmiş olabilir.

Çalışmanın bir diğer basamağını oluşturan postmodernizm ve postmodernlik, Mavi Kadife filminin ilk 15 dakikası üzerinden örneklendirilmeye çalışılmıştır. Kimilerine göre modernizmin reddi sayllarak pek çok yönden eleştiri yapan postmodernizm, eleştiri getirdiği yapıların yerine alternatifler yaratma süreci kapsamında değerlendirilmektedir. Bu kapsamda Kesit 2'de genel çekim ile yer alan sahneleme dikkat çekmektedir. İtfaiyecinin araç üzerinde kameraya bakarak el sallaması akla Godard'ın kullandığı oyuncu yönetimini getirmektedir. Modern anlatıda oyuncunun bir an kameraya bakarak rolüne devam etmesi, postmodern anlatıda değişiklik yaşamıştır. Bu değişikliği haber veren sahne ise çalışmanın Kesit 2 alanında yer almaktadır. İtfaiyecinin kameraya bakarak el sallaması aracın yavaşça kadrajdan çıkması, modern anlatının sonunun gelmiş olduğunun ilânı niteliğini taşımaktadır. Kimilerine göre ise modernizmin devamı sayılan postmodernizm, sinemada da bu karşıtlığı içerisinde barındırmaktadır. Modern anlatıda kullanılan efekt geçişleri postmodern anlatıda da kullanılmaktadır. Bunun örneği ise Kesit 4'te karşımıza çıkmaktadır. Burada da sahne arası geçişlerde tıpkı modern anlatıda bulunan açılma ve kararma efektleri kullanılmıştır. Ayrıca filmin ilk 15 dakikasında modern anlatıdaki gibi erkeğin kadından daha fazla sahnelenmesi fark edilmektedir. Mavi Kadife'nin ilk 15 dakikasında erkek 33, kadın 19 kez sahnelenmiştir. Bu durumda postmodern anlayışta yer alan Mavi Kadife filminin de toplumsal cinsiyet odaklı incelenmesi gerektiğini hatırlatmaktadır.

Tezatlıkların terimi olan postmodernizm, Mavi Kadife filminde bir yandan güzel ve sakin kasaba hayatını anlatırken bir yandan da karanlık ve karmaşık kasaba hayatını iç içe sunmaktadır. Kesit 6, Kesit 7, Kesit 8 ve Kesit 9'da ki kalp krizi sahnesini Lynch, farklı bir üslup ile betimlemiștir. Gerçekliğin değil, onun bir yansımasının anlatıldığı postmodern anlatıda, kalp krizi hayatın akışı içinde olağan bir durum olarak gösterilmiştir. Erkek karakterin (baba), kalp krizi geçirdiği sırada bir köpeğin kadraja girmesi sanki her şey yolundaymışçasına karakterin elindeki hortumdan zıplayarak su içmesi, bir bebeğin bahçede dolaşırken o anı görmesi, hemen ardından böcek yuvasına yapılan yakın çekim, Lynch tarafından rahatsız edici şekilde kullanılmıştır. Modern anlatıdan farklı olarak zamanın belirsizliğinin işlendiği filmde, zamanı belirlemek adına mizansen incelendiğinde dahi net bir çıkarım yapılamamaktadır. Ayrıca Kesit 11'de izleyicinin tanıştığı erkek karakterin (Jeffrey) üzerindeki giysiler, Serseri Âşıklarda alışkın olduğumuz modern erkekte yer alan erkek-fötr şapkasigara üçlemesini bize sunmamaktadır. Mavi Kadife filminin ilk 15 dakikasında sadece 1 kez dedektifin elinde gösterilen sigara ile aslında modern bireyliğin belirtisi olarak artık sigaranın kullanılmadığını, postmodern dönemde sigaranın zor işlerde görev alan kişiler tarafından kullanıldığına vurgu yapılmaktadır. Ek olarak postmodern anlatıdaki karakterler olayları çözüme ulaştıran kişiler olarak değil, çözüm sürecindeki eleman şeklinde konumlandırılmıştır. Tek bir gerçekliğin bulunmadığını savunan postmodernizm, bu durumu incelenen Mavi Kadife filminde 
erkek karakterin (Jeffrey), kesik kulak bulmasının ardından sahnelenen Kesit 14 ve Kesit 15'te yansıtmıştır. Kesit 14'te karanlık bir merdivenden aşağı bakan Jeffrey'nin, belirsizliklerle dolu bir zamana kapı araladığının betimlemesi yapılmıştır. Hemen ardından gelen Kesit 15 ise televizyondan yansıyan bir görüntüyü kadraja almaktadır. Burada tekrardan bilinmeyen başka bir erkek karakterin, merdivenlerden yukarı doğru çıkması gösterilmiştir. Böylece Kesit 14 ve Kesit 15, izleyicide Jeffrey’in içinde bulunduğu durum hakkında kafa karışıklığına yol açıldığı yönünde değerlendirme yapılması yanlış sayılmamaktadır. Serseri Âşıklarda modern anlatımda benimsenen dış mekân çekiminde cadde/yol/sokak 37, iç mekân 8 kere sahnelenmiștir. (Filmin ilk 15 dk.) Mavi Kadife filminde ise cadde/yol/sokak 14, iç mekân 8 kere sahnelenmiştir. (Filmin ilk 15 dk.) Bu durum postmodern anlatıda mekân seçimlerinin, hem modernizmle ortak olduğunu hem de olmadığını göstermektedir.

\section{Sonuç ve Değerlendirme}

Aydınlanma Çağı ile birlikte başlayan modernizm süreci temelinde; özgürlük, hak, eşitlik ve kardeşlik gibi kavramları getirmiştir. Söz konusu kavramlar bireylerin bilincinin dönüşmesine neden olmuş ve toplum dinamiklerinin değişmesine yol açmıştır. Modernizm, yeni oluşumları beraberinde getirirken aynı zamanda geçmişin izlerini de silmeye başlamıştır.

Eskiden bağların koparılması, yerine yeni bir şeylerin söylenebilmesi amacını taşıyan modernizm; klasik, kalıplaşmış ve standartlara bağlı olguları sonuna kadar eleştirmekte ve onların yerini alabilecek yeni olguların meydana getirilmesinde öncülük etmektedir. Siyasetten ekonomiye, edebiyattan sanata, kültürden topluma çeşitli alanlarda farklı biçimler yer almış olan modernizm, literatürde kesin olarak tanımlanamamıştır. Fakat modernizme genel anlamda hem kültürü ilgilendiren hem de estetizme değinen bir terim olarak yaklaşmak yanlış sayılmamaktadır. $\mathrm{Bu}$ duruma bağlı gelișen modernlik ise modernizmden ne ayrı değerlendirilmekte ne de aynı değerlendirilmektedir. Modernlik, özü gereği kapsamlı olguları anlatmak için kullanılmaktadır. On sekizinci yüzyılın Batı dünyasında yaşanan toplumsal değişimlerin anlamlandırılmasında sıklıkla kullanılan modernlik, zamanla küresel boyutta etkisini arttırmıştır.

Modernizme karşı geliş ya da modernizmin devamı şeklinde açıklanmaya çalışılan postmodernizmin ise literatürde tek bir kavramı bulunmamaktadır. Bu bağlamda postmodernizm, modernizmden farklı yeni bir söylem olduğu ya da olmadığı konusunda tartışmalara yol açmaktadır. Çalışmada postmodernizmle ele alınan postmodernlik, modernlikten sonraki aşamaları belirmek için kullanılmaktadır. Modernlikte sağlanmaya çalışılan değişimlerin ne derece başarılı olduğuna ya da olamadığına vurgu yapmaktadır. Postmodernizm, modernizmde savunulan tek bir gerçekliğin mümkün olmadığını belirtmektedir. Fakat bu söylem aslında onun da kendisiyle çeliştiğini göstermektedir. Çünkü postmodernizm, tek bir gerçek/ doğru yok dediğinde aslında kendisinin de tek doğru/gerçek olamayacağını düşündürmektedir. İkili karşıtlıklarla dolu olan modernizm ve postmodernizm kültürel, siyasal, ekonomik yapılar hâricinde çeşitli sanat dallarını da etkilemiştir. Sinema alanındaki filmler de modernizmi ve postmodernizmi kendisine konu edinmiştir. Çalışmada ele alınan Jean-Luc Godard'ın "Serseri Âșılklar" ve David Lynch'in "Mavi Kadife" filmleri modernlik ve postmodernlik ekseninde ele alınarak modernizmin ve postmodernizmin örneklendirilmesi yapılmaya çalışılmıştır. 
Göstergebilimsel analizin kullanıldığı çalışmada her iki filmin de ilk 15 dakikası ele alınmıș ve değerlendirilmiştir. Bu bağlamda modernizm anlayıșının karakterlerde, mekân seçiminde, kurguda ve çeşitli yapılarda, Serseri Âşıklar filminde etkin olduğu söylenebilmektedir. Modern dönemin modern insanının betimlendiği, bunu yaparken aynı zamanda kurgu ve çekim tekniklerinde klasik anlatıdan farklı olarak benimsenen yeniliklerin ortaya konulmaya çalışıldığı filmde, izleyicinin filme yabancılaşması amaçlanmıştır. Söz konusu bu durum, karakterlerin kameraya doğru bakarak konuşmasında kendisini belli etmiştir. Modern dönemde, modernlikle ilişkilendirildiği bilinen sigara-fötr şapka-gazete-araba vb. unsurlar sıklıkla kadrajda görülmektedir. Postmodern anlatıda ise örnek olarak ele alınan Mavi Kadife filmi, modern anlatıda var olan üslup ve biçime hem göndermelerde bulunmuş hem de bazılarını kendisi de kullanmaya devam etmiştir. Özellikle kurguda açılma ve kararma efektinin kullanılması modern anlatıda yer alan tarzın devam ettiğinin göstergesi sayılmaktadır. Fakat gerçeklik öğesinin tek bir anlam üzerinden açıklanamaması, karakterlerdeki farklılaşmalar ve olayların gelişme süreci yeni bir anlayışın benimsendiğini açıkça göstermektedir. Bu durum, postmodernin getirdiği olay örgüleri arasındaki nedensellik bağını koparmaya yönelik olarak algılanabilir. Ayrıca Mavi Kadife filminde yapılan çekimlerin bazılarında rahatsız edici şekilde yakın planlar da kullanılmıştır. Huzursuzluk ve sakinlik temalarının birbirini izlediği filmde, yapılan çekimler anlamı/anlamsızlığı kuvvetlendirmiştir.

Literatürde yer alan modernizm ve postmodernizm karışıklığı, sinemada örnek filmler üzerinden betimlenmeye çalışılmıştır. Birbirinden kesin çizgilerle ayrılamadığı bilinen modernin ve postmodernin etkileri, incelenen filmler üzerinde de görüldüğ̈ gibi net sınırlara sahip sayılmamaktadır. Bu iki terim, hem birbirinden beslenen hem de birbirinden uç noktalarda ayrışan aynı bütünü farklı şekillerde yorumlama perspektifidir.

\section{Kaynakça}

Bauman, Z. (2003). Modernlik ve Müphemlik, (İ. Türkmen, Çev.). İstanbul: Ayrıntı Yayınları.

Barthes, R. (1979). Göstergebilim İlkeleri, (B. Vardar-M. Rifat, Çev.). Ankara: Kültür Bakanlığı Yayınları.

Baudrillard, J. (2011). Simülakr ve Simülasyon, 6. b., (O. Adanır, Çev.). Ankara: Doğubatı Yayınları.

Best, S. ve Kellner, D. (1998). Postmodern Teori: Eleştirel Soruşturmalar, (M. Küçük, Çev.). İstanbul: Ayrıntı Yayınları.

Çüçen, K. (2006). “Batı Aydınlanmasının Düşünsel Kökenleri ve Eleştirisi”, Muğla Üniversitesi Sosyal Bilimler Enstitüsü Dergisi, Özel Sayı: 25-34.

Demir, Y. (2001). Modernizmden Postmodernizme Geçiş Sürecinin Dinamikleri, Yayımlanmamış Yüksek Lisans Tezi, Sakarya Üniversitesi Sosyal Bilimler Enstitüsü, Sakarya.

Derrida, J. (2001). Writing and Difference, (Translated by A. Bass ). London: Routledge. Faure, P. (1995). 'Rönesans', İstanbul: İletişim Yayınları.

Harvey, D. (2012). Postmodernliğin Durumu, (S. Savran, Çev.). İstanbul: Metis Yayınlarl. 
Horkheimer, M. ve Adorno, T.W. (1996). Aydınlanmanın Diyalektiği II (O. Özügül, Çev.). İstanbul: Kabalcı Yayınevi.

Hoy, D. (2007). Jacques Derrida, Çağdaş Temel Kuramlar içinde, (Der.) Quentin Skinner, (A.Demirhan, Çev.). Ankara: Vadi Yayınları.

Jeanniere, A. (1994). “Modernite Nedir?” (N. Tutal-Küçük, Çev.). Modernite versus Postmodernite, (Mehmet Küçük), Ankara: Vadi Yayinları.

Karabulut, M., Biricik, İ. (2017). "Postmodern Edebiyatın Ne'liĞi" HiKMET-Akademik Edebiyat Dergisi [Journal of Academic Literature], Gelenek ve Postmodernizm Özel Sayısı(3): 34-45.

Karaduman, S. (2010). Modernizmden Postmodernizme Kimliğin Yapısal Dönüşümü, Journal of Yasar University, 17(5): 2886-2899.

Karasar, N. (2018). Bilimsel Araştırma Yöntemi, Ankara: Nobel Yayıncılık.

Lyotard, J. F. (1994). Postmodern Durum, (A. Çiğgdem, Çev.). Ankara: Vadi Yayınları.

Murphy, J. W. (2000). Postmodern Sosyal Analiz ve Postmodern Elestiri, (H. Arslan, Çev.). İstanbul: Paradigma Yayınları.

Özkiraz, A. (2003). Modernleşme Teorileri ve Postmodern Durum, Konya: Çizgi Kitabevi.

Sarup, M. (2010). Post-Yapısalcılık ve Postmodernizm, (A. Güçlü, Çev.). İstanbul: Kırk Gece Yayınları.

Şaylan, G. (1999). Postmodernizm, Ankara: İmge Yayınları.

Vatandaş, C. (2015). Modern Çöküş-İnsanın Modern Halleri, İstanbul: Açılım Kitap.

İnternet Kaynakları

Best,S. ve Kellner, D. (t.y.). Postmodern Theory, Erişim: 28.11.2018, https://pages. gseis.ucla.edu/faculty/kellner/essays/postmoderntheorych1.pdf 